\title{
Urban landscape influences the composition of butterflies in public parks and fragments in Southern Brazil
}

\author{
J. H. Pérez¹, E. Carneiro, F. G. Gaviria-Ortiz, M. M. Casagrande and O. H. H. Mielke \\ Laboratório de Estudos de Lepidoptera Neotropical, Departamento de Zoologia, Universidade Federal do Paraná, \\ CEP 81531-980, Curitiba, PR, Brazil \\ ${ }^{1}$ Corresponding author.Email: johan.perez@uptc.edu.co
}

Keywords: Conservation; Diversity; Landscape features; Lepidoptera.

\begin{abstract}
Terrestrial ecosystems across the world experience large-scale and widespread urbanization, causing a sharp decline, fragmentation and segregation of natural landscapes. Nevertheless, fragments of natural habitats that are found within the largest cities may still be capable of preserving high species diversity that amount to a large portion of the regional biodiversity. Knowing which variables of the urban landscape promote the conservation of species' assemblages in large cities helps us to implement measures that support biodiversity conservation. We sampled the butterfly assemblages of eight urban forest fragments in Curitiba (Southern Brazil), from September 2015 to April 2016. At each site, richness, diversity and composition of butterflies were estimated and then correlated to nine landscape variables measured at two spatial scales (buffers of 250 and $750 \mathrm{~m})$. A total of 298 species were recorded in these fragments, representing $53.7 \%$ of all species known to occur in the city. Despite of great difference in the size of the fragments (between 27 and $56.3 \mathrm{ha}$ ), there were no significant differences in species richness among the fragments. On the other hand, some significant correlations were observed between landscape variables and butterfly composition other than the fragment itself, such as the paved area and total forested area present around the fragments. These results reinforce the idea that the conservation of natural fragments in urban areas requires public policies that enhance not only the habitat quality of the fragment itself, but also enrichment of the landscape around them.
\end{abstract}

Abbreviations: BA-Bosque do Alemão; BCI-Bosque Capão da Imbuia; BTr-Bosque dos Tropeiros; BJII-Bosque João Paulo II; BRM-Bosque Reinhard Maack; BTa-Bosque Tatuquara; CCA-Canonical Correspondence Analysis; FoA-Forest area; DFractal dimension; Dist-Fragment and the green belt around the urban matrix; FrP-Fragment perimeter; FrA-Fragments area; ISTf-Mean fragment isolation index; OGA-Open green area; PB-Parque Barigui; PaA-Paved area; CON-Proportion of the connection area; ZM-Zoológico Municipal.

\section{Introduction}

Urbanization is currently recognized as one of the main causes of habitat loss, mostly promoted by the rapid growth and concentration of human populations in large urban centers (Grimm et al. 2008). Consequently, large cities experience shrinking, fragmentation, and isolation of their natural ecosystems (Hardy and Dennis 1999, Pickett et al. 2001), resulting in highly altered landscapes.

Although isolated green areas, parks or fragments in urban landscapes are usually easily accessible for humans, biodiversity studies in urban ecosystems are still comparatively scarce (Bolund and Hunhammar 1999, Koh and Sodhi 2004, Ramírez-Restrepo et al. 2007, McKinney 2008, RamírezRestrepo and Halffter 2013). This obstructs an accurate evaluation of which variables are more intrinsically associated with biodiversity loss, such as size, shape, isolation, and connectivity of natural habitats, as well as the quality of the matrix (Dennis and Hardy 2001, DeSouza et al. 2001).

Since different organisms have particular biological characteristics, a variety of responses to the same anthropomorphic change may be expected by different taxa (Didham et al. 1998, DeSouza et al. 2001, Hill and Curran 2003). Butterflies have often been used as model organisms for biodiversity monitoring because included are both groups of species which increase and decrease their population sizes in response to habitat modification (McDonnell and Pickett 1990, Ramírez-Restrepo and Halffter 2013). This makes them an ideal group to study the fragmentation caused by urbanization (Ruszczyk 1986, Blair and Launer 1997, Brown and Freitas 2000, Hogsden and Hutchinson 2004). Butterflies may be attracted to flowers and use host plant species that are cultivated either in home gardens or urban and park areas (Blair and Launer 1997, Bergerot et al. 2011).

Hence, this relationship directly affects their assemblage structure across the urban landscape, as the vicinity of forest fragments varies, e.g., being highly isolated by buildings, or partially connected by tree lines along street sidewalks, or by private backyard gardens (McDonnell and Pickett 1990, Felson and Pickett 2005, Grise et al. 2016). Therefore, the butterfly assemblages present in fragments isolated by an urban matrix are not only subjected by the quality of the fragments they inhabit, but also by factors that are external to the fragment itself. Knowing which urban landscape variables influence the patterns of butterfly assemblages may help to implement measures that support biodiversity conservation in large cities around the world. Aiming this goal, the cur- 
rent study sampled the butterfly assemblages of eight forest fragments located in a large urban matrix in Southern Brazil, expecting to find more diverse assemblages related to both larger fragments and fragments less isolated by paved areas. Similarly, we also hypothesized that these landscape measurements affect assemblage composition, thus revealing that larger and less isolated fragments have more similar species composition compared to smaller and more isolated fragments. Finally, we compared the total butterfly richness collected in these fragments with the total richness already recorded for the city.

\section{Material and methods}

\section{Study area}

The city of Curitiba is located in the state of Paraná, Southern Brazil (Fig. 1) at 900-1000 m asl, Curitiba was originally covered by mixed Ombrophilous Forest (Araucaria Forest). The annual temperature ranges from $12.9^{\circ} \mathrm{C}$ to 22.5 ${ }^{\circ} \mathrm{C}$, with $16.4^{\circ} \mathrm{C}$ mean temperature. The climate is temperate oceanic climate $(\mathrm{Cfb})$, according to the Köppen classification (García 1973), and annual average precipitation is around $1600 \mathrm{~mm}$ (IPPUC 2012). Curitiba has 16 forests, 393 gardens, 54 lakes, 21 parks, 418 environmental parks, and four private reserves of municipal natural heritage (Grise et al. 2016). These green areas are present all over the city, although they are more concentrated in the northern and western zones (Vieira and Biondi 2008).

\section{Butterfly sampling}

We sampled butterflies using insect nets in eight fragments in the city: Bosque do Alemão (BA), Bosque Capão da Imbuia (BCI), Bosque dos Tropeiros (BTr), Bosque João Paulo II (BJII), Bosque Reinhard Maack (BRM), Bosque Tatuquara (BTa), Parque Barigui (PB), and Zoológico Municipal (ZM) (Fig. 1).

Four samplings were performed by two researchers in each fragment between September 2015 and April 2016, from 09:30 to $16: 30$. Specimens were identified with the assistance of specialists and/or by comparison with type specimens (Warren et al. 2009). Species' nomenclature follows Lamas (2004) for Papilionoidea, and Mielke (2005) for Hesperiidae. Voucher specimens were deposited in the Entomological
Figure 1. Geographical location of fragments sampled in the city of Curitiba, Paraná, Brazil. $750 \mathrm{~m}$ and $250 \mathrm{~m}$ buffer.

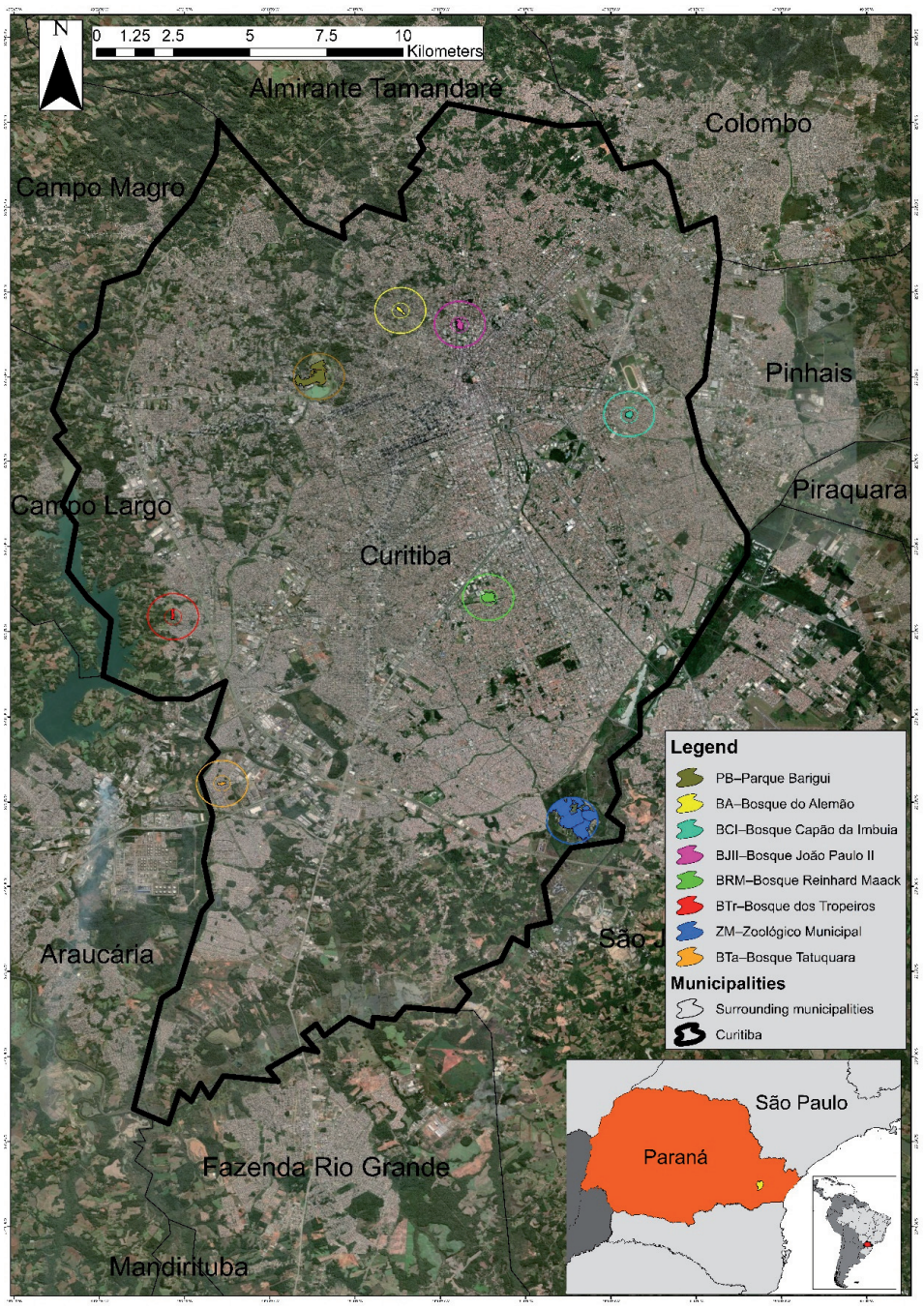


Table 1. Geographical and landscape metrics for the eight sample sites where butterfly assemblages were sample in Curitiba, Paraná, Brazil.

\begin{tabular}{|c|c|c|c|c|c|c|c|c|}
\hline & $\begin{array}{l}\text { Bosque do } \\
\text { Alemão }\end{array}$ & $\begin{array}{c}\text { Bosque } \\
\text { Capão da } \\
\text { Embuia }\end{array}$ & $\begin{array}{l}\text { Parque dos } \\
\text { Tropeiros }\end{array}$ & $\begin{array}{c}\text { Bosque Joao } \\
\text { Paulo II }\end{array}$ & $\begin{array}{c}\text { Bosque } \\
\text { Reinhard } \\
\text { Maack }\end{array}$ & $\begin{array}{l}\text { Bosque do } \\
\text { Tatuquara }\end{array}$ & $\begin{array}{l}\text { Parque } \\
\text { Barigui }\end{array}$ & $\begin{array}{c}\text { Jardim } \\
\text { Zoologico }\end{array}$ \\
\hline Latitude & -25.41 & -25.44 & -25.50 & -25.41 & -25.49 & -25.54 & -25.43 & -25.56 \\
\hline Longitude & -49.29 & -49.22 & -49.35 & -49.27 & -49.26 & -49.34 & -49.31 & -49.24 \\
\hline Area (ha) & 3.1 & 3.9 & 1.4 & 5.5 & 9.8 & 1.8 & 29.1 & 103.4 \\
\hline Perimeter & 868 & 756 & 585 & 986 & 1343 & 687 & 3417 & 7363 \\
\hline $\begin{array}{l}\text { Distance to } \\
\text { greenbelt }\end{array}$ & 2180 & 4960 & 0 & 3392 & 4817 & 610 & 0 & 0 \\
\hline \multicolumn{9}{|l|}{ (250 m scale) } \\
\hline Forested areas & 0.5 & 0.1 & 0.6 & 0.6 & 0.2 & 0.5 & 0.2 & 0.0 \\
\hline $\begin{array}{l}\text { Open green } \\
\text { areas }\end{array}$ & 3.6 & 3.6 & 6.7 & 4.4 & 2.3 & 3.0 & 1.6 & 0.4 \\
\hline Paved areas & 12.8 & 12.5 & 7.2 & 9.6 & 8.3 & 14.4 & 3.5 & 0.2 \\
\hline \multicolumn{9}{|l|}{ (750 m scale) } \\
\hline Forested areas & 15.1 & 1.4 & 22.1 & 6.8 & 6.3 & 19.0 & 18.5 & 12.1 \\
\hline $\begin{array}{l}\text { Open green } \\
\text { areas }\end{array}$ & 39.8 & 36.7 & 51.9 & 36.8 & 32.5 & 53.8 & 47.3 & 15.1 \\
\hline Paved areas & 119.0 & 134.8 & 91.9 & 127.3 & 129.0 & 101.1 & 56.0 & 9.4 \\
\hline
\end{tabular}

Collection of Pe. Jesus Santiago Moure (DZUP), at the Universidade Federal do Paraná.

\section{Data analysis}

Hill numbers were used to estimate butterfly assemblage diversity for each sampled fragment (Hill 1973). This method has two major benefits compared to conventional diversity metrics: 1 . A better appreciation of how the weight assigned to rare species alters the diversity estimations; 2 . The possibility to directly compare different diversity profiles. Traditionally, Hill numbers are represented by weights (q) equal to 0,1 or 2 . When $\mathrm{q}=0$, the differences in the abundance of the species are ignored, which means that only the value of species richness is taken into account to designate the diversity in a sample. When $\mathrm{q}=1$, the index is equal to that of Shannon diversity (H'), allocating a low weight to discern the differences in the abundances of rare species. When $q=2$, the index is equivalent to the Simpson diversity $(\chi)$ index, giving greater value of importance to rare species (Leinster and Cobbold 2012).

Because Hill numbers are also sensitive to sample size (Chao et al. 2014), interpolation and extrapolation curves were drawn to make fair comparisons between incomplete samples (Chao and Jost 2012), according to the methodology proposed by Chao et al. (2014). In each fragment sampled, the diversity calculated based on the interpolation and extrapolation method was compared with one another and with the total number of butterfly species already recorded from Curitiba (Pérez et al. 2017a). The curves were calculated using the iNEXT package for R environment ( $\mathrm{R}$ Core team 2016)
To test the influence exerted by the urban landscape on butterfly diversity, nine categories of the surrounding landscape structure were measured: Forest area (FoA), Open green area (OGA), Paved area (PaA), other Fragments area (FrA), and Fragment perimeter ( $\mathrm{FrP})$. Additionally, we measured the distance between the center of the fragment and the green belt around the urban matrix (Dist), to represent how distant the fragment is from the more continuous natural landscape present around the city. We also measured the mean fragment isolation index (ISTf), which is the average of the distances from the fragment being investigated and all the neighboring fragments; proportion of the connection area (CON), calculated by dividing the number of pixels representing forested areas by the total number of landscape pixels; and fractal dimension (D), which is the slope of the regression line between the logarithm of the area by the logarithm of the perimeter, considering all the fragments that compose the landscape mosaic. Additionally, we tested the effect of spatial scale in our results by calculating the landscape metrics using two different buffer sizes ( 250 and $750 \mathrm{~m}$ ). All the geographic information was processed and analyzed using QGIS 2.14.3 (Quantum GIS 2016) and Google Earth Pro (2016).

To confirm the correlations between the urban landscape and butterfly diversity, all landscape variables were fited onto an ordination of butterfly composition produced by Canonical Correspondence Analysis (CCA) using the "envfit" function available in the "vegan" package (Oksanen et al. 2015). Through this procedure, the predictive power of all landscape variables under investigation can be assessed at the same time on the composition of the assemblages. The same procedure was used to test if different subsets of butterfly groups (e.g., 
families and subfamilies) responded similarly to the results obtained by all species.

\section{Results}

A total of 5,655 individuals were collected from all eight fragments sampled, representing 298 butterfly species (Table 1). Although fragment samples differed in the numbers of butterflies collected (between 561 and 997 individuals), no significant differences were observed in terms of species richness (from 116 to 143 species, Table 2, Fig. 2a) among the fragments.

All fragments displayed similar sample coverage, although a unique shape in the curve of BA was observed in comparison to all other interpolation-extrapolation curves (Fig. 2a). The confidence intervals showed a large overlap when $q=0$, lending support to the non-detection of significant differences in terms of species richness among the fragments. However, the greater the weight assigned to the occurrence of a rare species, the higher the diversity estimated for BA, unlike ZM, whose diversity is clearly less than all

a

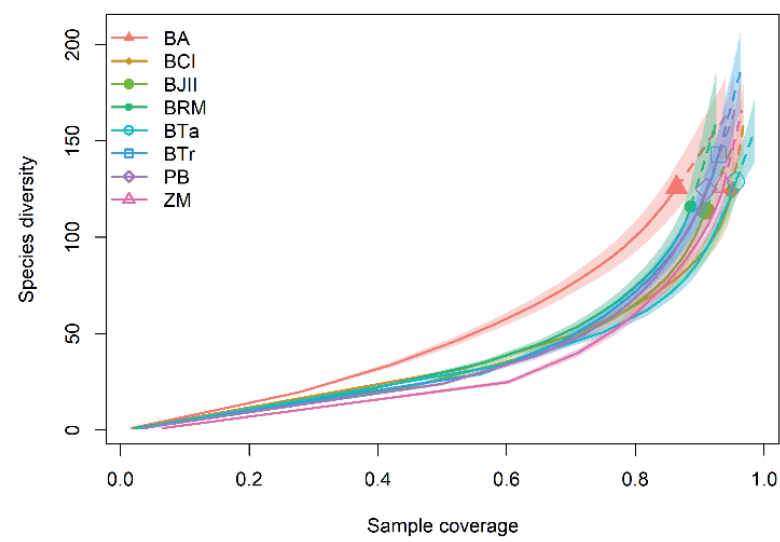

the other localities (Figs. 2b,c). Therefore, urban fragments revealed no differences in their richness, despite their contrasting abundances.

Several correlations between the landscape variables and butterfly composition were found, especially for family subsets, such as Hesperiidae, Lycaenidae and Riodinidae (Tables 3,4). Paved area $(\mathrm{PaA})$ was the landscape factor which showed more significant correlation with distinct families of butterflies, although the Fragment area (FrA), Fragment perimeter (FrP), distance between fragment and the green belt around the urban matrix (Dist), Proportion of the connection area (CON) and Fractal Dimension (D) also showed significant results to specific butterfly taxa. Also, we could not find any particular scale size showing more frequent correlations with the composition of butterflies. distinct results of correlations measured at distinct geographical scales (250 and 750 m, Figs. 3a,b). Although some correlations do change at different scales, they represent that different taxa/landscape relationship are sometimes better observed in smaller or larger scales.

b

Order $q=1$

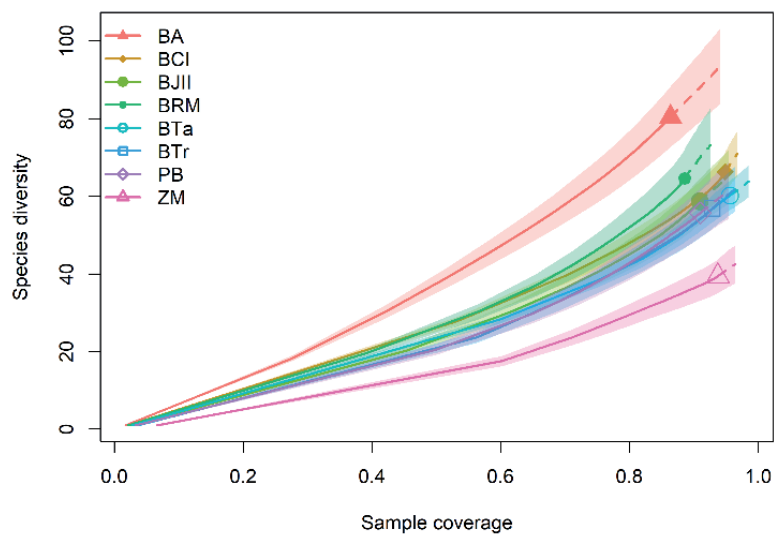

C

Order $q=2$

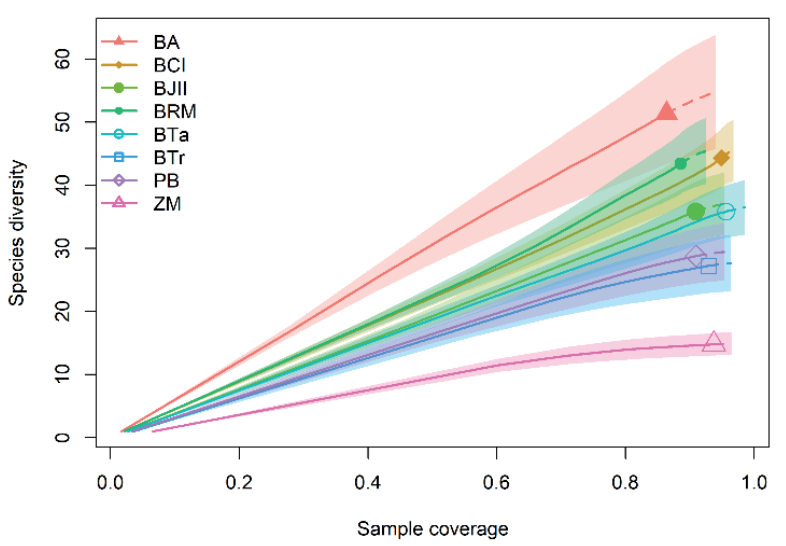

Figure 2. Butterfly diversity in eight urban forest fragments using Hill numbers: (a) $q=0$ - total number of richness, (b) $q=1-$ number of abundant species $\left(\mathrm{H}^{\prime}\right)$ and $(\mathbf{c}) \mathrm{q}=2$ - number of very abundant species in the sample $(\lambda)$ with $95 \%$ confidence intervals. Interpolation based on the coverage, continuous lines (interpolation) and discontinuous lines (extrapolation). 
Table 2. Abundance $(\mathrm{N})$ and Species richness $(\mathrm{S})$ total per park and families of the butterfly community, species represented by a single individual "singletons", $q=0$ total number of species richness extrapolated, $q=1$ number of extrapolated abundant species and $q=2$ number of very abundant species extrapolated in the sample, present in the eight urban forest fragments of Curitiba, Paraná, Brazil. The observed number of individuals is represented in parentheses.

\begin{tabular}{lrrrrrrrr}
\hline & $\begin{array}{c}\text { Bosque } \\
\text { Alemão }\end{array}$ & $\begin{array}{c}\text { Bosque } \\
\text { Capão da } \\
\text { Imbuia }\end{array}$ & $\begin{array}{c}\text { Bosque dos } \\
\text { Tropeiros }\end{array}$ & $\begin{array}{c}\text { Bosque João } \\
\text { Paulo II }\end{array}$ & $\begin{array}{c}\text { Bosque } \\
\text { Reinhard } \\
\text { Maack }\end{array}$ & $\begin{array}{c}\text { Bosque } \\
\text { Tatuquara }\end{array}$ & $\begin{array}{c}\text { Parque } \\
\text { Barigui }\end{array}$ & $\begin{array}{c}\text { Zoológico } \\
\text { Municipal }\end{array}$ \\
\hline $\mathrm{N}$ & 414 & 845 & 864 & 561 & 501 & 997 & 633 & 840 \\
$\mathrm{~S}$ & 126 & 124 & 143 & 114 & 116 & 129 & 125 & 127 \\
Hesperiidae & $40(112)$ & $46(283)$ & $48(169)$ & $41(194)$ & $48(150)$ & $45(244)$ & $43(165)$ & $42(132)$ \\
Lycaenidae & $12(16)$ & $9(31)$ & $5(8)$ & $9(20)$ & $6(16)$ & $12(27)$ & $6(14)$ & $5(12)$ \\
Nymphalidae & $56(209)$ & $55(472)$ & $68(622)$ & $51(290)$ & $46(310)$ & $61(625)$ & $57(402)$ & $60(495)$ \\
Papilionidae & $5(36)$ & $5(14)$ & $2(7)$ & $1(2)$ & $2(2)$ & $1(2)$ & $4(11)$ & $2(3)$ \\
Pieridae & $8(25)$ & $6(38)$ & $8(38)$ & $9(40)$ & $9(17)$ & $6(55)$ & $6(21)$ & $9(50)$ \\
Riodinidae & $5(16)$ & $3(7)$ & $12(20)$ & $3(15)$ & $5(6)$ & $4(44)$ & $9(20)$ & $9(148)$ \\
Singletons & 8 & 7 & 12 & 7 & 12 & 13 & 7 & 9 \\
q=0 & 182 & 151 & 176 & 163 & 176 & 165 & 181 & 144 \\
q=1 & 92 & 70 & 62 & 65 & 74 & 63 & 61 & 44 \\
q=2 & 55 & 45 & 28 & 37 & 47 & 37 & 30 & 15 \\
\hline
\end{tabular}
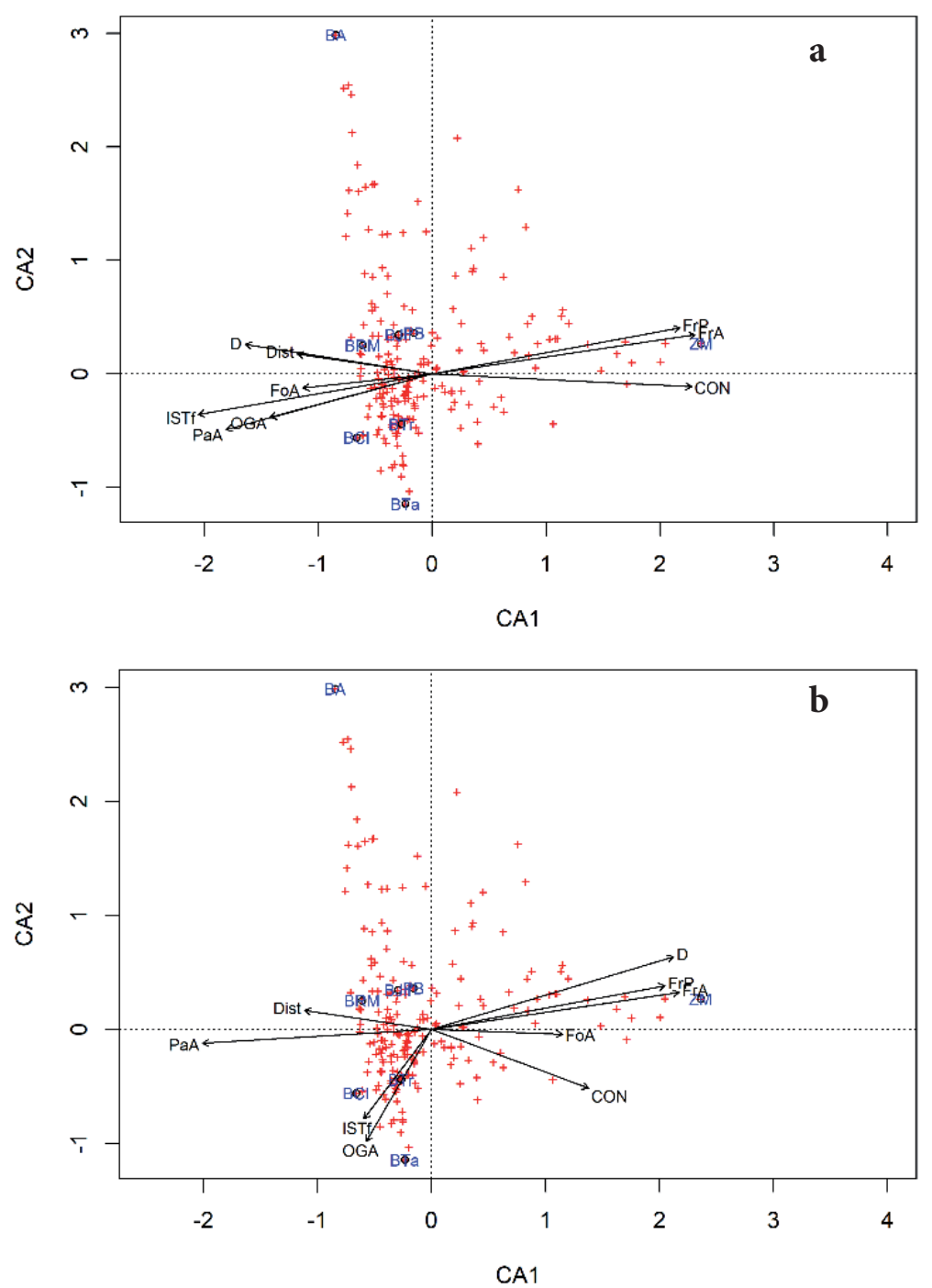

Figure 3. Canonical Correspondence Analysis (CCA), among the nine landscape variables and butterfly species $(*)$ in eight urban forest fragments in Curitiba city. (a) $250 \mathrm{~m}$ buffer, (b) $750 \mathrm{~m}$ buffer. 


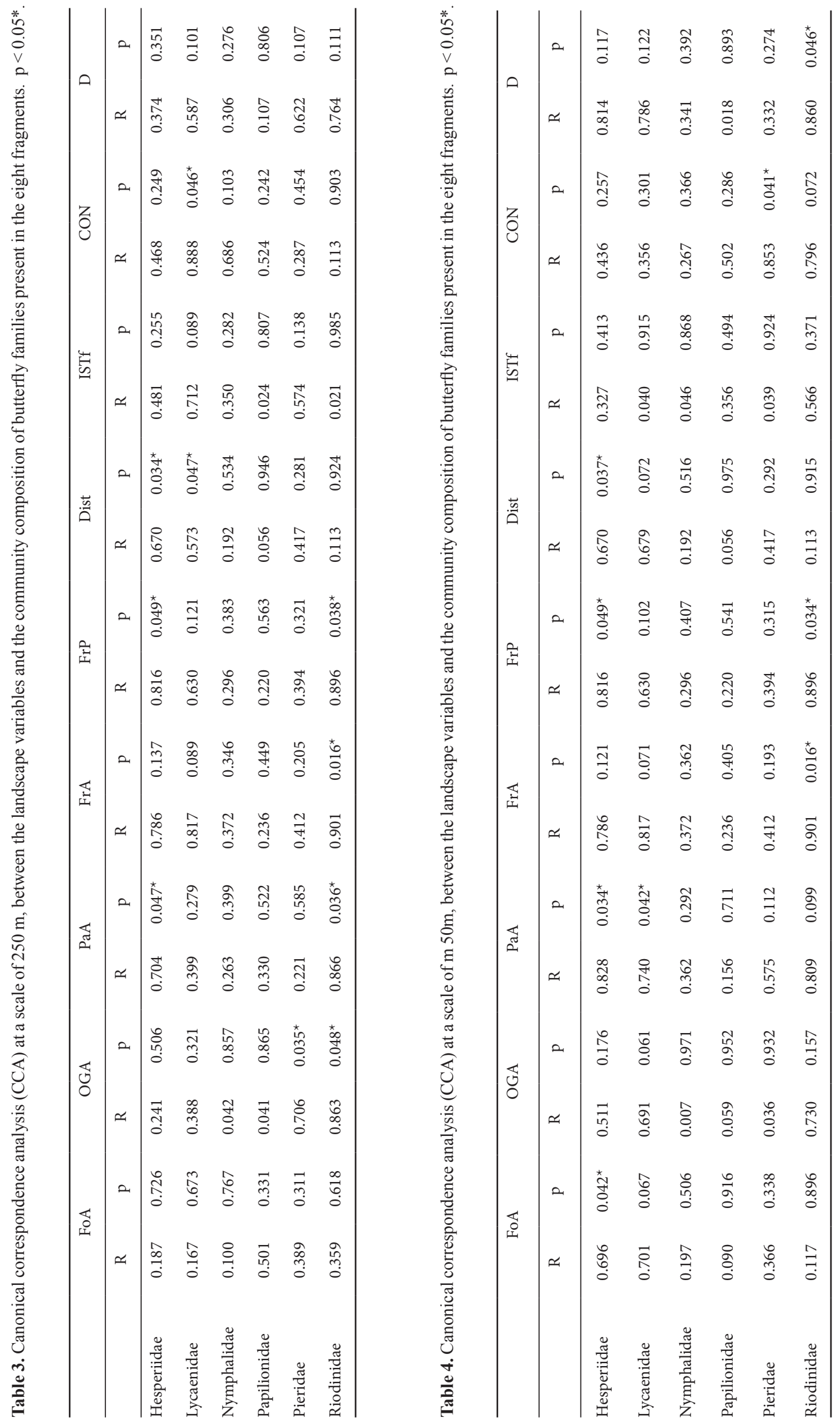




\section{Discussion}

The total species richness recorded in this study corresponds to $53.7 \%$ of all butterfly species already recorded from Curitiba in almost 80 years (Pérez et al. 2017a). This percentage is particularly relevant, considering the restricted geographical and temporal sampling of this study. Furthermore, all species' extrapolation curves produced non asymptotic geometries, confirming the difficulties in sampling all species from a specific locality within a limited number of sampling hours (Brown and Freitas 2000, Iserhard et al. 2010, Fattorini 2013), even when habitats are extremely reduced (Brown et al. 2018) and/or intensely modified (Harvey and Villalobos 2007). Considering all these variables, it is reasonable to infer that small natural fragments present in tropical urban cities may serve as refuges for many butterfly species that inhabit the city, and therefore they have a primary role in preserving biodiversity.

Obviously, fragment size is an important parameter to estimate how many species a fragment can harbor, given that larger fragments have greater probability to encompass more heterogeneous and complex environments. This is highly relevant for Lepidoptera because both larvae and adults may use distinct plant species as their main food resource (Wilcox et al. 1986, Baz and Garcia-Boyero 1995, Connor et al. 2000, Matter 2000, Steffan-Dewenter and Tscharntke 2000, Zschokke et al. 2000, Wettstein and Schmid 2001, Hamer et al. 2003, Krauss et al. 2004). However, the diversity pattern observed in the present study did not exhibit a positive relationship between fragment area and species richness. For instance, the highest diversity indexes were found at BA, despite the fact that it is the smallest fragment compared to all other sampled areas. This fragment corresponds to one of the most visited parks in the city, where some nectar-producing plants are cultivated annually, thus offering abundant nectar resources for butterflies. In fact, studies that quantified nectar resources have found a strong association between this variable and butterfly species richness or species incidence (Hardy and Dennis 1999, Hogsden and Hutchinson 2004, Clark et al. 2007). Because such gardening practices are common in urban parks, an increase in nectar resources in selected fragments may hinder species area relationships in urban landscapes, as more species will be attracted to parks that include flowers in their regular management.

But landscape variables also interact with the biological diversity, particularly when they interfere with the ability of organisms to disperse and colonize new regions (Macarthur and Wilson 1967). Therefore, apart from fragment size, the connectivity and isolation of fragments are also common mechanisms that strongly affect butterfly assemblage structure in urban ecosystems (Blair and Launer 1997, Clark et al. 2007, Bergerot et al. 2011). For example, the total size of the paved area $(\mathrm{PaA})$ around a fragment is most likely the principal impediment for butterflies to disperse. In contrast, green spaces, such as side-street lawns, backyard gardens, and tree or shrub lines along streets and avenues could act as stepping stones for butterfly dispersal, or even be used as host plant or nectar resource by more generalist species (Bergerot et al. 2011, Soga and Koike 2013). In general, the measurements of paved areas, buildings, lawns, trees and bushes have been used as surrogates to gradients of urbanization, thus being associated with the richness and incidence of butterflies (Blair and Launer 1997, Hardy and Dennis 1999, Hogsden and Hutchinson 2004). Beyond that, they also evidently play a role on how butterflies disperse across a urban landscape (Bergerot et al. 2012).

In our study, paved area $(\mathrm{PaA})$ and open green areas (OGA) were the most common factors associated with butterfly assemblage structure, and different taxonomic groups of butterflies responded distinctly to these landscape variables. For instance, assemblage composition of Hesperiidae, Lycaenidae and Riodinidae were more affected by the size of the paved area, while Heliconiinae and Ithomiinae assemblages showed more correlations with open green areas. This disparity is known to occur in butterflies because certain lineages conserve distinct ecological traits, hostplant lineages, number of generations per year and dispersal ability (GarcíaBarros 2008). As these traits affect the way distinct species are distributed across urban landscape (Blair and Launer 1997, Clark et al. 2007, Bergerot et al. 2011), distinct butterfly taxa are expected to disperse more efficiently than others depending on the kind of matrix surrounding the fragment (Nowicki et al. 2014).

Besides the quality of the matrix, one additional landscape feature influenced butterfly assemblage structure in our case. The fragments sampled in this study also varied in their shape, some of them having more irregular perimeter than others, thus increasing the size of edge-related habitats, instead of interior environments. Edge habitats are known to influence butterfly dispersal (Schultz and Crone 2001), and to harbor distinct assemblages according to their ecological properties (Ries and Sisk 2008). In fact, several studies have reported unique butterfly assemblages related to these habitats, suggesting that light, type of vegetation cover and composition of edge habitats favor their presence (Hill et al. 1995, Laurance et al. 2002, Hamer et al. 2003, Ramírez-Restrepo and Halffter 2013, Lemes et al. 2015, Pérez et al. 2017b). As in the results of $\mathrm{PaA}$ and OGA, we found that the same butterfly families (Hesperiidae, Lycaenidae and Riodinidae) are influenced by variations in fragment shape, showing that these groups might present sets of species with more intrinsic preferences for edge/interior environments. This is an important finding for urban planning because many parks within the city are crossed by large streets and avenues, thus producing more irregular perimeters and reducing the size of more conserved interior forest areas. Since the decline of interior environment species of butterflies happens at multiple spatial scales (Brown and Hutchings 1997, Leidner et al. 2010), the more complex the fragment is the less is the probability to find these butterfly species across the urban landscape.

Finally, the ecological literature shows how geographic scale can alter the way we detect correlations between landscape variables and organism diversity (Chave 2013). Although the differences on scale size used in this study seems narrow, relevant results have demonstrated that very restrict scales $(80-200 \mathrm{~m})$ are more effective in showing how but- 
terfly assemblages are correlated to local landscape (Hogsden and Hutchinson 2004, Ribeiro et al. 2012). In our case, both scales $(250 \mathrm{~m}$ and $750 \mathrm{~m})$ yielded a very similar number of noteworthy correlations. According to Clark et al. (2007), correlations of assemblages and landscape measurements are dependent on which measurements of assemblages are taken, as well as on which landscape variable is being correlated. Generally, species' host-plant associations within the immediate vicinity of the fragment are reported as the mechanism responsible for the findings that shows that butterflies respond better to landscapes at smaller scales. Because of that, adults and larvae would usually present similar geographical distribution (Blair and Launer 1997, Ribeiro et al. 2012). On the other hand, when larger scales give more robust results, the high dispersal ability of butterflies and the use of larger areas to forage are suggested as the most likely explanation (Clark et al. 2007, Ribeiro et al. 2012). The present results agree with both mechanisms, supporting that distinct butterfly families may regard one or other of these ecological traits in most of their species. Therefore, such ecological traits of butterflies are of great value not only to estimate their influence on the distribution patterns of assemblages, but also to select a more appropriate spatial scale to be used in experiments.

\section{Conclusion}

Compared to other South American cities (Olivares and Tapias 2010, Lazzeri et al. 2011, Marín et al. 2014, Pérez et al. 2017b), all forest fragments sampled in Curitiba showed high species richness, showing that landscapes under extreme impact can still harbor a substantial fraction of the original diversity. However, preserving the quality of urban fragments should be extended beyond the mere conservation of the fragment itself, to include modifications that promote connectivity between fragments. For instance, a simple exchange of paved sidewalks to tree lines or lawns would itself favor a fraction of butterfly species to disperse among isolated fragments and thus increases the number of organisms that occupy large metropoles. More importantly, the preservation of interior environments inside natural fragments is fundamental to assure the population dynamics of butterfly species dependent of this kind of habitat.

Acknowledgements. To Drs D. Grisales, T. Sepulveda, L. R. Restrepo, T. Zacca, G. L. Gutierrez, R. Sánchez, F. Dias, and D. R. Dolibaina, for helping on species identification and manuscript review. To the Secretaria do Meio Ambiente of Curitiba (SEMA) for giving the permits to collect in the parks. Also, the Conselho Nacional de Desenvolvimento Científico e Tecnológico $(\mathrm{CNPq})$ for the financial support.

\section{References}

Baz, A. and A. Garcia-Boyero. 1995. The effects of forest fragmentation on butterfly communities in central Spain. J. Biol. 22(1):129-140.

Bergerot, B., B. Fontaine, R. Julliard and M. Baguette. 2011. Landscape variables impact the structure and composition of butterfly assemblages along an urbanization gradient. Lands. Ecol. 26(1):83-94.

Bergerot, B., T. Merckx, H. Van Dyck and M. Baguette. 2012. Habitat fragmentation impacts mobility in a common and widespread woodland butterfly: do sexes respond differently? $B M C$ Ecology 12:5.

Blair, R.B. and A.E. Launer. 1997. Butterfly diversity and human land use: Species assemblages along an urban grandient. Biol. Conserv. 80(1):113-125.

Bolund, P. and S. Hunhammar. 1999. Ecosystem services in urban areas. Ecol. Econ. 29(2):293-301.

Brown, B.V., A. Borkent, P.H. Adler, D. de S. Amorim, K. Barber, D. Bickel, S. Boucher and M.A. Zumbado. 2018. Comprehensive inventory of true flies (Diptera) at a tropical site. Communic. Biol. 1(1):1-21.

Brown, K.S. and A.V.L. Freitas. 2000. Atlantic forest butterflies: Indicators for landscape conservation. Biotropica 32(4):934956.

Brown, K.S. and R.W. Hutchings. 1997. Disturbance, fragmentation and dynamics of diversity in the butterflies of the Amazon forest, In: Laurance, W.F, and R.O.Jr. Bierregaard (eds), Tropical Forest Remnants. The University of Chicago Press, Chicago. pp. 91-110.

Chao, A., N.J. Gotelli, T.C. Hsieh, E.L. Sander, K.H. Ma, R.K. Colwell and A.M. Ellison. 2014. Rarefaction and extrapolation with Hill numbers: a framework for sampling and estimation in species diversity studies. Ecol. Monog. 84(1):45-67.

Chao, A. and L. Jost. 2012. Coverage-based rarefaction and extrapolation: Standardizing samples by completeness rather than size. Ecology 93(12):2533-2547.

Chave, J. 2013. The problem of pattern and scale in ecology: what have we learned in 20 years? Ecol. Letters 16(1):4-16.

Clark, P.J., J.M. Reed and F.S. Chew. 2007. Effects of urbanization on butterfly species richness, guild structure, and rarity. Urb. Ecosys. 10(3):321-337.

Connor, E.F., A.C. Courtney and J.M. Yoder. 2000. Individuals-area relationships: The relationship between animal population density and area. Ecology 81(3):734-748.

Dennis, R.L.H. and P.B. Hardy. 2001. Loss rates of butterfly species with urban development. A test of atlas data and sampling artefacts at a fine scale. Biol. Conserv. 10(11):1831-1837.

DeSouza, O., J.H. Schoereder, V. Brown and R.O. Bierregaard Jr. 2001. A theoretical overview of the processes determining species richness in forest fragments. In: Bierregaard, R.O.Jr., Gascon, C., Lovejoy, T.E. and Mesquita, R.C. (eds), Lesson from Amazonia, the Ecology and Conservation of a Fragmented Forest. Yale University Press. New Haven. pp. 13-21.

Didham, R.K., J.H. Lawton, P.M. Hammond and P. Eggleton. 1998. Trophic structure stability and extinction dynamics of beetles (Coleoptera) in tropical forest fragments. Proc. Royal Soc. Biol. Sci. 353(1367):437-451.

Fattorini, S. 2013. Regional insect inventories require long time, extensive spatial sampling and good will. PLOS ONE 8(4):62-118.

Felson, A.J. and S.T.A. Pickett. 2005. Designed experiments: new approaches to studying urban ecosystems. Front. Ecol. Environ. 3(10):549-556.

García, A. 1973. Modificaciones al sistema de clasificación climática de Köppen. Instituto de Geografía. Universidad Nacional Autónoma de México.

García-Barros, E. 2008. Body size, egg size, and their interspecific relationships with ecological and life history traits in butterflies 
(Lepidoptera: Papilionoidea, Hesperioidea). Biol. J. Linn. Soc. 70(2):251-284.

Google. s.f. 2016. [Map of Curitiba, Brasil in Google maps]. https:// www.google.com.co/maps/place/Curitiba/Brazil/25.4956847, 49.4273653,11zdata=en. Accessed 12 Sep 2016.

Grimm, N.B., S.H. Faeth, N.E. Golubiewski, C.L. Redman, J. Wu, X. Bai and J.M. Briggs. 2008. Global change and the ecology of cities. Science 319(5864):756-760.

Grise, M.M., D. Biondi and H. Araki. 2016. Distribuição espacial e cobertura de vegetação das tipologias de áreas verdes de Curitiba, PR. Flor. Amb. 23(4):498-510.

Hamer, K.C., J.K. Hill, S. Benedick, N. Mustaffa, T.N. Sherratt, M. Maryati and V K. Chey. 2003. Ecology of butterflies in natural and selectively logged forests of northern Borneo: the importance of habitat heterogeneity. J. Appl. Ecol. 40(1):150-162.

Hardy, P.B. and R.L.H. Dennis. 1999. The impact of urban development on butterflies within a city region. Biol. Conserv. 8(9):1261-1279.

Harvey, C.A. and J.A.G. Villalobos. 2007. Agroforestry systems conserve species-rich but modified assemblages of tropical birds and bats. Biol. Conserv. 16(8):2257-2292.

Hill, J. K., K.C. Hamer, L.A. Lace and W.M.T. Banham. 1995. Effects of selective logging on tropical forest butterflies on Buru, Indonesia. J. Appl. Ecol. 32(4):754-760.

Hill, J.L. and P.J. Curran. 2003. Area, shape and isolation of tropical forest fragments: effects on tree species diversity and implications for conservation. J. Biol. 30(9):1391-1403.

Hill, M.O. 1973. Diversity and evenness: A unifying notation and its consequences. Ecology 54(2):427-432.

Instituto de Pesquisa e Planejamento Urbano de Curitiba (IPPUC) 2012. Curitiba em dados. https://www.lovemondays.com.br/ trabalhar-na-instituto-de-pesquisa-planejamento-urbano-de-curitiba-ippuc/avaliacoes. Accessed 18 Sep 2016.

Hogsden, K.L. and T.C. Hutchinson. 2004. Butterfly assemblages along a human disturbance gradient in Ontario, Canada. Can. J. Zool. 82(5):739-748.

Iserhard, C.A., M.T. Quadros, H.P. Romanowski, M. and M. Souza. 2010. Borboletas (Lepidoptera: Papilionoidea e Hesperioidea) ocorrentes em diferentes ambientes na Floresta Ombrófila Mista e nos Campos de Cima da Serra do Rio Grande do Sul, Brasil. Biol. Neo. 10(1):309-320.

Koh, L.P. and N.S. Sodhi. 2004. Importance of reserves, fragments, and parks for butterfly conservation in a tropical urban landscape. Ecol. Appl. 14(6):1695-1708.

Krauss, J., T. Schmitt, A. Seitz, I. Steffan-Dewenter and T. Tscharntke. 2004. Effects of habitat fragmentation on the genetic structure of the monophagous butterfly Polyommatus coridon along its northern range margin. Mol. Ecol. 13(2):311-320.

Lamas, G. 2004. Cheklist: Part 4A. Hesperioidea - Papilionoidea. In: Heppner, J.B. (ed.), Atlas of Neotropical Lepidoptera. Volume 5A. Association for Tropical Lepidoptera/Scientific Publishers, Gainesville, Florida.

Laurance, W.F., T.E. Lovejoy, H.L. Vasconcelos, E.M. Bruna, R.K. Didham, P.C. Stouffer, C. Gascon, R.O.J. Bierregaard, S.G. Laurance and E.M. Sampaio. 2002. Ecosystem decay of Amazonian forest fragments: A 22-year investigation. Conserv. Biol. 16:605-618.

Lazzeri, M.G., M.E. Bar and M.P. Damborsky. 2011. Diversidad del orden Lepidoptera (Hesperioidea y Papilionoidea) de la ciudad Corrientes, Argentina. Rev. Biol. Trop. 59(1):299-308.
Leidner, A.K., N.M. Haddad and T. E. Lovejoy. 2010. Does tropical forest fragmentation increase long-term variability of butterfly communities? PLOS ONE 5(3):5-34.

Leinster, T. and C.A. Cobbold. 2012. Measuring diversity: the importance of species similarity. Ecology 93(3):477-489.

Lemes, R., A.P.S. Carvalho, T.C. Ribeiro and A.B.B. Morais. 2015. Borboletas de áreas verdes urbanas de Santa Maria, sul do Brasil (Lepidoptera: Papilionoidea). SHILAP 43(169):95-111.

Macarthur, R.H. and E.O. Wilson. 1967. The Theory of Island Biogeography. University Princeton Press, New Jersey.

Marín, M.A., C.F. Álvarez, C.E. Giraldo, T.W. Pyrcz, S.I. Uribe and R. Vila. 2014. Mariposas en un bosque de niebla andino periurbano en el valle de Aburrá, Colombia. Rev. Mex. Biol. 85(1):200-208.

Matter, S.F. 2000. The importance of the relationship between population density and habitat area. Oikos 89(3):613-619.

McDonnell, M.J. and S.T.A. Pickett. 1990. Ecosystem structure and function along urban-rural gradients: An unexploited opportunity for ecology. Ecology 71(4):1232-1237.

McKinney, M.L. 2008. Effects of urbanization on species richness: A review of plants and animals. Urban Ecosyst. 11(2):161-176.

Mielke, O.H.H. 2005. Catalogue of the American Hesperioidea: Hesperiidae (Lepidoptera). Sociedade Brasileira de Zoologia. Curitiba.

Nowicki, P., V. Vrabec, B. Binzenhöfer, J. Feil, B. Zakšek, T. Hovestadt and J. Settele. 2014. Butterfly dispersal in inhospitable matrix: rare, risky, but long-distance. Landsc. Ecol. 29(3):401-412.

Oksanen, J., F.G. Blanchet, R. Kindt, P. Legendre, P.R. Minchin, R.B. O'Hara, G.L. Simpson, P. Solymos, M.H. Stevens and H. Wagner. 2015. Vegan: community ecology package. R package vegan, vers. 2.2-1. Worl. Agro. Cent. 3:7-81.

Olivares, H.E. and G.O. Tapias. 2010. Estudios preliminares de Mariposas Diurnas (Lepidóptera: Rhopalocera) en el Jardín Botánico del Táchira Parque Natural Paramillo, Estado Táchira, Venezuela. Entomotrópica 22(3):185-189.

Pérez, J.H., F.G. Gaviria-Ortiz, W.I.G. Santos, E. Carneiro, O.H.H Mielke and M.M. Casagrande. 2017a. Long term survey of the butterfly fauna of Curitiba, Paraná, Brazil: How does a scientific collection gather local biodiversity information? (Lepidoptera: Papilionoidea). SHILAP 45(179):433-446.

Pérez, J.H., R.E. Sánchez and D.J. Salcedo. 2017b. Diversidad de mariposas presentes en la Escuela de Policía Rafael Reyes de Santa Rosa de Viterbo, Boyacá, Colombia (Lepidoptera: Papilionoidea). SHILAP 45(178):343-352.

Pickett, S.T.A., M.L. Cadenasso, J.M. Grove, C.H. Nilon, R.V Pouyat, W.C. Zipperer and R. Costanza. 2001. Urban ecological systems: Linking terrestrial ecological, physical, and socioeconomic components of metropolitan areas. Rev. Ecol. Syst. 32(1):127-157.

QGIS Development Team. 2016. QGIS geographic information system 2.14.3. Open Source Geospatial Foundation Project, URL http://qgis.osgeo.org

Ramírez-Restrepo, L., P. Chacón De Ulloa and L.M. Constantino. 2007. Diversity of diurnal butterflies (Lepidoptera: Papilionoidea and Hesperioidea) in Santiago de Cali, Valle del Cauca, Colombia. Rev. Colomb. Entom. 33(1):54-63.

Ramírez-Restrepo, L. and G. Halffter. 2013. Butterfly diversity in a regional urbanization mosaic in two Mexican cities. Land. Urban Plan. 115:39-48. 
R Core Team. 2016. R: A language and environment for statistical computing. R Foundation for Statistical Computing, Vienna, Austria. ISBN 3-900051-07-0, URL http://www.Rproject.org

Ribeiro, D.B., R. Batista, P.I. Prado, K.S. Brown and A.V.L. Freitas. 2012. The importance of small scales to the fruit-feeding butterfly assemblages in a fragmented landscape. Biol. Conserv. 21(3):811-827.

Ries, L. and T.D. Sisk. 2008. Butterfly edge effects are predicted by a simple model in a complex landscape. Oecologia 156(1):75-86.

Ruszczyk, A. 1986. Ecologia urbana de borboletas, I. O gradiente de urbanização e a fauna de Porto Alegre, RS. Rev. Bras. Biol. 46(4):675-688.

Schultz, C.B. and E.E. Crone. 2001. Edge-mediated dispersal behavior in a prairie butterfly. Ecology 82(7):1879-1892.

Soga, M. and S. Koike. 2013. Patch isolation only matters for specialist butterflies but patch area affects both specialist and generalist species. J. For. Res. 18(3):270-278.

Steffan-Dewenter, I. and T. Tscharntke. 2000. Butterfly community structure in fragmented habitats. Ecol. Letters 3(5):449-456.

Vieira, C.H.S.D. and D. Biondi. 2008. Analysis of land cover change in the municipality of Curitiba, state of Paraná - Brazil, from 1986 to 2004, using Landsat-TM imagery. Rev. Arvore. 32(3):479-487.

Warren, A.D., J.R. Ogawa and A.V.Z. Brower. 2009. Revised classification of the family Hesperiidae (Lepidoptera: Hesperioidea) based on combined molecular and morphological data. Syst. Entomol. 34(3):467-523.

Wettstein, W. and B. Schmid. 2001. Conservation of arthropod diversity in montane wetlands: effect of altitude, habitat quality and habitat fragmentation on butterflies and grasshoppers. J. Appl. Ecol. 36(3):363-373.

Wilcox, B.A., D.D. Murphy, P.R. Ehrlich and G.T. Austin. 1986. Insular biogeography of the montane butterfly faunas in the Great Basin: Comparison with birds and mammals. Oecologia 69(2):188-194.

Zschokke, S., C. Dolt, H.P. Rusterholz, P. Oggier, B. Braschler, G.H. Thommen, E. Lüdin, A. Erhardt and B. Baur. 2000. Short-term responses of plants and invertebrates to experimental small-scale grassland fragmentation. Oecologia 125(4):559-572.

Received August 5, 2019

Revised December 3, 2019 Accepted December 7, 2019

\section{Supplementary material}

Table S1. List of butterfly species found in eight forest fragments of Curitiba, Paraná, Brazil, between September 2015 and April 2016.

The file may be downloaded from www.akademiai.com. 